人が放射線障害を意識し始めたのは，1895年の Roentgen 教授によるX線の発見以来である。同教授の報 告後, 約 4 力月でX線による脱毛や皮店の外傷が発表 されている。X線障害はまずこのように身体の表面を 覆っている皮有の障害として認識された。しかし，そ の後 2 年くらいの間にX線による急性障害の例も報告 されていて，かなり早くから身体内部の障害にも関心 が寄せられていたとい光る。

\section{I. 放射線と血液の変化}

血液の障害についてはドイッの外科医 Heinecke が 実鈳結果を古く 1903年, 1904 年に発表している。これ は現在からみても立派なものといえる。HeineckeはRa の照射によってマウスが死亡するという実験にヒント を得て，Raの放射能と同しょらな性質の X 線にも同 じ作用があるのではないかと考皇て，マウスにX線照 射を行なった。その結果マウスは死に, 解剖してみる 上脾缄が小さくなっていた。彼はさらにモルモットで む実験を行い，次いで鬼でX線の照射実験を行なっ た。この鬼の実験では赤血球と白血球を経時的に調 へ，白血球数は激減するが，赤血球数は減少の程度が 軽かったことを確かめている。Heinecke性結論として 「X線はリンバ組織を唚してリンパ球が減少する。赤 血球数の減少が白血球数の隇少ほど目立たないのは, 赤血球と白血球がそれぞれ異なった寿命を持っている ためではなかららか」とている。これらのことはそ の後確かめられており，Heineckeの実験は当時として 見事な結論を得たものといえる。

ヒトについては，当時は血液学が発達していなかっ たため正確な記録はないが，1910年代から造血障害で 死亡したと思われる症例が報告されている。これらの 症例はいずれも長年月放射線に曝される仕事に従事し
ていたすので,最後は顔色が青くなり，歯限などから出 血して死亡している。これらの例を解剖してみると， リンメ゚組織は萎縮し，骨䯣では血球を作る母細胞(後 述)が少なくなっていた。有名な Curie 夫人る，1934 年 7 月 4 日, 再生不良性筫血で息を引き之った。当時 の血液学的記録は充分でないが，原因としては研究や 第一次大戦で行なったX線カーによる検診を通じて， 長年にわたって放射線被懪をしたためと考克られる。 さらに忘れてはならないのが，米国に批る夜光叙 料工場従業員の障害例である。1917 年から 1924 年に わたって米国ニニージャージー州のある夜光塗料工場 に延ぺ 800 人の女子従業員が㕍われていた。このう ち，1〜2年あるいはそれ以上の期間を常に同工場で 䖝光鉒料による計器の文字書きに從事していた者の 中から，白血球減少を伴う重症の賽血や，上下顎骨の 壤㾝さらに骨肉腫の発生がみられた。これは Martland の詳紐な調査によってRa中㶳と判明した。すな わち，使用された鳘料はZnSと Ra,メゾトリウムおよ びラジオトリウムの混合物で，これに少量のCd,Cuお よび $\mathrm{Mg}$ を加えていた。大部分の女子従業員は細かい 仕事をする時，筆の先をなめる習慣があり 1 週間に15 $\sim 215 \mu \mathrm{g}$ 程度放射性物質が摂取されたと推定されてい る。これは体内被曝による造血障害の例といえる。 Martlandの報告を検討すると，これらの筫血例は， 一見再生不良性貨血であるが，骨䯣の所見などから， 白血病との類似点もあり，血液学的には学者の関心を ひく賓血である。

Significance of Hematological Findings in Case of Medical Examination for Radiation Employee, Toshiyuki KUMATORI.

（1977年 11月9日 受理） 
以上，放射線被曝と造血障害の主な歴史を 2,3 振り 返ってみた。Haineckeの実験以外はいずれる長期間に わたる被曝に上るものである。短時間に大量の全身被 曝のあった例は広島・長崎に叔ける原爆が最初である。 原爆では熱括よび爆風による被害が大きいが，放射線 (中性子線， $\gamma$ 線)による被害も大きかったことは周知 の事実である。急性障害に淤ける血液の変化およびそ れと被㩧線量との関係などが，各方面の努力で判明し ている。また，放射性降下物からの大線量被曝例とし ては，1954年の日本人漁夫23名，マーシャル群島住民 239 名, 米国人28名の被曝があるが，この中の大線量被 曝者には造血障害がみられている。また，原子力研究 施設での大線量被曝事故例も少数ながら報告され，詳 しい血液変化の所見が記載されている。

\section{II. 造血の仕組み}

ここでとトの造血について簡単に説明する。人間は 胎児期汇は肝や脾です造血を行なっているが，生後は 骨䯣でのみ造血を行う。ただし，血球の中でリンバ球 はリンパ節や脾でる作られている。骨䯣は骨に取り团 まれておりジェリー状のものである。成人では造血を 活発に営んでいる赤色䯣は春椎骨のような短い骨の骨 觬や胸骨・助骨・晹骨などのような扁平骨の骨䯠で，大 腿骨の上らな長い骨では骨端部の骨㖪が赤色䯣で，他 は脂肪化した黄色檤である。

ヒトの血管内を流れている末梢血中の血球はそれそ れ寿命がある。赤血球は約 120 日，血小板は $5 \sim 10$ 日，白 血球は数日，またりンバ球は毒命の短い(数時間)もの から長いもの(10年あるい性それ以上)まであるといわ れている。いずれにしろ，骨䯣の中で炏幼若な細胞か ら成熟細胞となって末梢血比出て，通常の数を保って いるのである。骨䯣の中では第 1 图に見るように，幼 若なるのから増殖拉よび成熟が行われる。現在は，寸

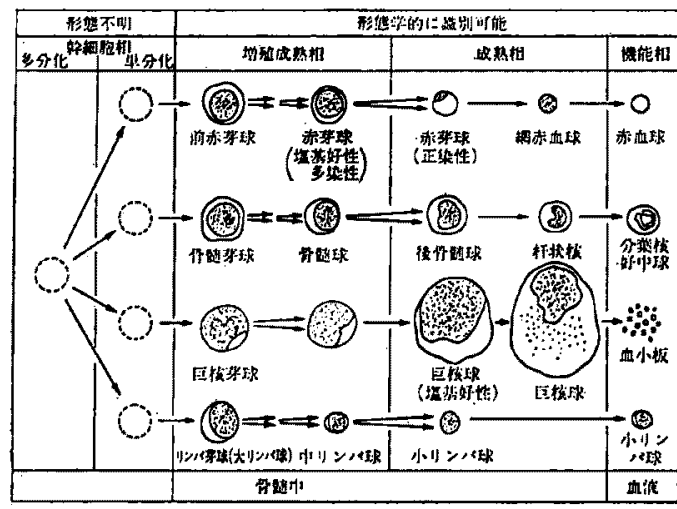

第1図造血細胞の增殖分化のモデル図
べての血球に共通しだ幹細胞”が最も若い細胞と考え られ，これは血液中を移動することができる。必要に 応して分裂，分化するものと考克られている。

\section{III. 血液検查の実際}

\section{1. 急性放射線障害之血液変化}

急性放射線障害の処置をするに当っては，被襮者の 被曝線量を知ることは大切である。しかし，大部分の 例では，被曝初期に線量を正確に知ることは困難で， 医学的妈㯰を臨床症状や諸検査の結果によって決めて 行がぱならないことが多い。この中で血夜学的検查 はその障害の程度を知る上に役立つるのの一つであ る。無論, この血液学的变化水上って被暴線量を正碓 に知るといったことはできない。

従来経験された事故的被瀑例について，被懪線量と 血液学的変化々の関係,特に末梢血中のリン八球，好中 球，栓球(血小板)についてデータを集めることが試み られている。その 1 例に第 1 表のよらなデータがある (1)。これは平均 $5 \mathrm{~cm}$ の深さでの全身吸收線量で,リン 球，好中球，栓球が正常値(平均値)の 25,50 打よび 75 \%低下するのに要する線量である。

第 1 表 種々の程度の血球数減少を生しるに 要する推定全身吸收楾量 (1)

\begin{tabular}{|c|c|c|c|}
\hline \multirow[b]{2}{*}{ 血 球 } & \multicolumn{3}{|c|}{ 正常值からの減少率に対する吸收楾量 } \\
\hline & $25 \%$ & $\begin{array}{l}(\mathrm{rad}) t^{t} \\
50 \%+t\end{array}$ & $75 \%+\dagger$ \\
\hline 栓 球 & 50 & 120 & 250 \\
\hline リンパ球 & 60 & 150 & 300 \\
\hline 好中球 & 80 & 190 & 390 \\
\hline
\end{tabular}

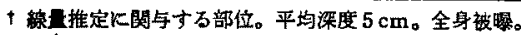

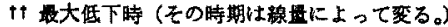

また一方, 被曝者の急性症状に基ついて，被曝者の 予後を考えたいくつかのカテゴリーが考えられている がこれと血液学的变化とを併わせると，血夜変化は障 害の程度を知る上に有力な指標となる。第 2 図(a) (c)は Wald らのカテラ゙リーでI〜群に分けて，そ れぞれの典型的な末梢血球数の变化を示したるのであ る(1)(2)。ここで各群の予後と大体の被曝線量を示すと 次のようになる。

I 群……..生存確実 $(10 \sim 160 \mathrm{rad})$

II 群……....体生存 $(200 \sim 400 \mathrm{rad})$

III 群……...生存可能 $(400 \sim 600 \mathrm{rad})$

VI 群……....生存はありそうるない $(600 〜 1,400 \mathrm{rad})$

$\nabla$ 群……..生存不可能 $(100,000 \mathrm{rad} \pm 50 \%)$

著者む ${ }^{192}$ Ir 線源からの $r$ 線被曝事故比いて，II 群と 同粎の血液变化を示した症例を徎耠したが，推定被曝 


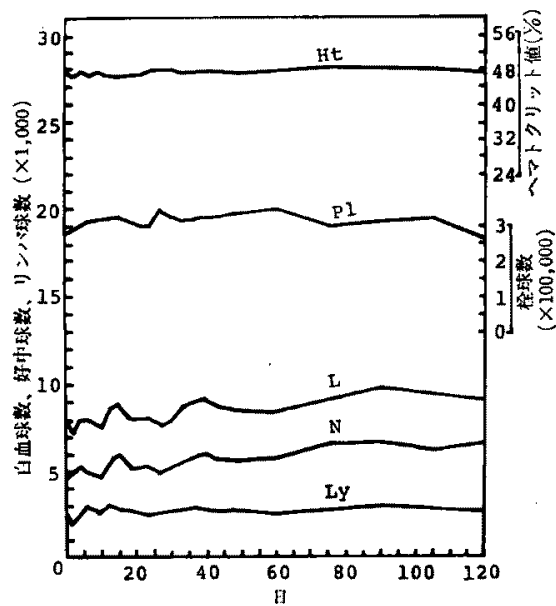

(a) カテゴリーI 群

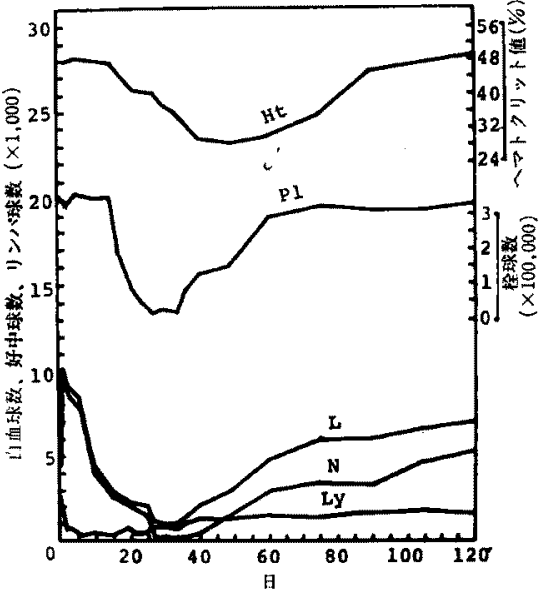

(b) カテゴリーII群

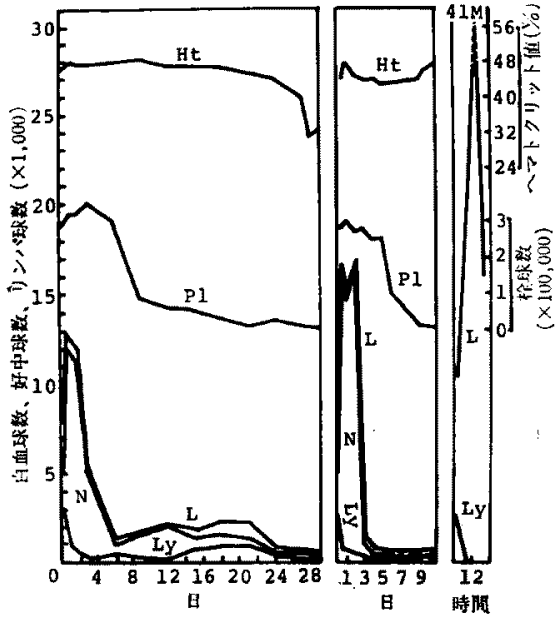

(c) カテゴリーII〜V群

L: Leucocytes(白血球数)，N: Neutrophils(好中球数) Ly: Iymphoeytes (リンバ球数), Pl: Platelets (栓玙数) Ht: Hematocrit(ヘアトクリット値)

第 2 图典型的血球数変化
線量む大体一致した。

このように血液検查の 1 つの意義は，大線量被瀑に 際してその障害の程度を推定し，医察処置を行らのに 極めて有用であることである。このため各人の平常の 変動範囲を知っておくことは役に立つことであるう。

2. 長期被曝と血液変化

(1) 白血球数の変化

放射線取扱者にとって最む関心を持つのは，長期被 曝と血球変化との関俰であうう。放射線取扱者の血液 学的変化に関しては，古くからかなりの報告がある。 しかし，1930年代，1940年代のるのには，これら血液 検查を受けた放射線取扱者の被曝線量測定が不充分な ので，血球数の変化が羿められるレペルを推定するこ とができなかった。

イギリスの Mayneord (3) は自己の勤務する病院の放 射線取扱者に関する検查結果と従来報告されている例 を併わせて次のように述べている。「Sievertは0.02 0.05R/day の線量で血液変化が生じると報告し，Knowlton は $0.2 \mathrm{R} /$ weekの線量で 2 年後, 白血球数，好中 球数,リンハ球数に軽度の低下をみた。0.01〜0.1R/ week では低下は有意ではなかった。 Mayneord 自身 は, $0.05 \sim 0.125 \mathrm{R} /$ week の線量で統計的には有意と はいえないような血球数低下を锤察した。」

これらは，いずれるグループとして見た場合に血球 数低下の攧向にあるといらことで，個人々ネについて は白血球数の変化などから，上述のような低線量被曝 のモニタリングはできない。

（2）その他の血液検查（主なるの）

(1) 二核リンパ球：これは成熟したリンパ球で， 核は明膫に二分していて，括のおのは小リンパ球の核 に相当している。このリンパ球は正常人では，リンパ 球10,000個につき 1 個，もしくは白血球30,000個につ き1個の割合で存在する。しかし，200 mR/week 程度 の被曝をするサイクロトロン従業員では，この二核り ンパ球が有意に增加しているという報告(4)(5)がある。 このよらなりンバ球はウィルス性矤患に際してる増加 するので，放射線被曝に特有なるのとはいい難い。

(2) Refractive neutral red bodies (RNRB): † ヌス線と中性赤を用いて末梢血球を染色(超生体染色) して顕微鏡下で観察すると，リンパ球に refractive bo-

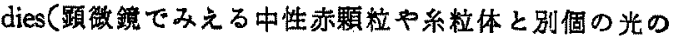
届折体)が原形質内に見える。0.05R/day の線量を受 ける放射線作耊者群では，奶照群に比べて RNRB が有 意増加しているといら(B)。

（3）栓球，赤血球の変化：放射線取扱者に栓球の 
大小不同が多く, 高色素性大厚性曾血の㑯向(赤血球の 厚さが增す)があるという報告すある(7)。

以上の諸観察は微量放射線の生物学的影響を知る上 で貴重なデータを提供するるのであるらが，被曝者之 対照群との間に統計学的に有意な差を得るためには莫 大な労力を要するので，実際の健康診断にこれらを応 用することは困難である。

\section{3. 血球染色体の変化}

1960年に末梢血培養によるリンパ球染色体の観察法 が確立 ${ }^{(8)}$ されて以来, この方法は放射線影響を知る上 にも応用されている。特に被曝線量の生物学的推定法 として広く利用されるようになった。さらに，放射線 被曝によるリンパ球染色体の異常は, 被曝後長年月に わたって保持され，かつ，その異常頻度は最初に受け た障害の程度とほぼ一致するので，被曝直後のみなら ず長い経過後でも，その障害の程度を推定するのに役 立つといら利点もある。

この染色体異常による被曝線量の推定は，現在では 非常な努力を払って，拉そらく短時間の被曝で $10 \mathrm{rad}$ 以上の線量なら推定でるであろう。しかし，佐々木 正夫氏る述べているように，低線量率被瀑の場合は問 題は簡単ではない。同氏は「低線量率被嚗の場合の一 般的傾向としては，被曝開始から積算線量の堌加に伴 って異常頻度はふえるが，間むなくブラトーに達し， 総線量がらえても異常頻度はふえなくなる。プラトー 值は線量率が高ければ高い」と述べている(日)。

また，内部被曝の場合は放射性核種の体内分布や排 出などが，体内のリンパ球にどのような影艟を持つか といら問題など，末解決の点が多々ある。

現行の医学的,生物学的検索法の中では, リンハ球染 色体暴常頻度の增加は低レヘル放射線の影響を知る上 では最る鋭敏なるのとい元らっしかし，現在の所で は結果が判明するのKかなりの手間を要するので，健 康診断に直らに応用することは無理である。

\section{IV. 血液検査の意義}

以上，放射線被曝と血夜変化との関保を概観してき たが，放射線健康診断に括ける血液検査の意義ならび にその価値についてまとめてみる。

まず，一般にわれわれの健康の程度を知る上では， 種々の検查を行なって多くの情報を得ることは有用な ことといえる。このような一般的見地からみると，血 液検查はそれなりの価值はある。しかし，放射線取扱 者が日常問題にしているような最大許容線量程度のレ
ペルの被曝では，血液の変化を検知することは極めて 困難であり，たとえある程度の变化が観察されたとし ても，てこに至るまでには多大の手間と労力を要し， またその変化は放射線被瀑で特異的に生したるのとは いい難いという点からみると，すでに述べたように血 液榆査でこの程度の被曝のモニタリングをすることは できない。

一方, 大線量被曝の場合には血液検査の結果は被曝 者の処着，予後の推定に亟めて重要な役割を果す。し かし，血球数などは個人差があるし，自然の変動もあ るため，大線量被暴の恐れのある作業者仙いては， 個人々々の正常範囲をよく捕捉して特く必要がある。 例总ば, 1964 年アメリカの Richland で生じ被懪事 故( $\gamma$ 線 と中性子線の混合被曝)で最大被㩧線量(109 $123 \mathrm{rem}) の$ 従業員のリンバ球数は一般人の正常範囲内 にあったが，この個人については明らかに平常の值よ り低かった。これ怔期的な血液桧査を実施して初め て観察し得ることである ${ }^{(10)}$ 。

また，放射線の晚発障害と考兄られている疾病には 血液疾患が含まれ(例えば白血病), その占める割合は 多い。このため，長期間の血液検查の記録は，不幸に る從業員がそのような疾病になった時，非常に重要な むのとなってくる。

以上，放射線取扱者の血液検査の意義について 2,3 の考察を加えたが，故射線取扱者の被懪管理が充分行 われることがまず大切である。また，血液検查の内 容, 回数などは各人の曝されている放射線の危険性の 如何によって決めるべきで，それらの決定は健康管理 に京任のある医者潐せるのが適当と考えられる。

\section{一至考文献一}

(1) WALD, N.: "Manual on Radiation Haematology", pp. 253 264 (1971), IAEA, Vienna.

(2) SAENGER, E.L. (ed.): "Medical Aspects of Radiation Accidents", p. 41 (1963), U.S. AEC, Washing. ton, D.C.

(3) MAYNEORD, W.V.: Brit. J. Radiol., 24, 525(1951).

(4) Ingram, M., Barnes, S.W.: Physiol. Rev., 75, 1765 (1949).

(5) Dobson, R.L., Chupp, M.M.: Proc. Soc. Exp. Biol. Med., 95, 360 (1957).

(6) Dickie, A., HempelmanN, L.H.: J. Lab. Clin. Med., 32, 1045 (1947).

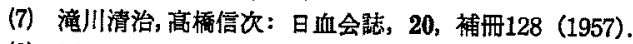

(8) MOORHEAD, P.S., et al.; Exp. Cell. Res., 20, 613 (1960).

（9）佐々木正夫: 東京医学, 82, 208 (1974).

(10) ChanteuR, J., Pellerin, P.: 前 出(1), pp. 369 372. 